\title{
A Research on Volatility in the Indian Stock Market with Special Reference to Nifty and Selected Companies Offinancial Service Sector of NSE of
}

\author{
M.Pushpalatha, J. Srinivasan, G. Shanmugapriya
}

\begin{abstract}
In recent years the increasing importance of the future market in the Indian markets has received considerable attention from researchers,academicians and financial analysis.the present study is undertaken with an attempt to determine the share price movements and its volatility of the selected ten companies of financial service sector, which is in nifty fifty companies list.The period of the study selected between January 2009 and December 2017.for examining the share price movements and its volatility, the researcher took descriptive statistics and for finding the volatility, kolmogorovsmirnovtest,from the results, among the selected ten financial service companies are not homogenous during the study period, and also examine the run test in Indian stock market is weak form efficient, the non-random behavior of the market has only short termimplications. Finally should take necessary steps to maintain its financial health and increase the market share in India.
\end{abstract}

Keywords: Indian Stock Market,Efficiency. Volatility, Nifty, Stock Index.Selected Companies.

\section{INTRODUCTION}

Capital market is a place for buying and selling of longterm financial claims. It is the market where transactions are made in long term securities such as stocks and bonds. The participants of this market includes various financial institutions, mutual funds, agents, brokers, dealers, individual investors and other borrowers and lenders of long term debt and equity capital. Capital market consists of two majorparts

1) Primary Market and 2) Secondary market.

The primary market or otherwise called as new issue market is one in which long term capital is raised by corporate directly from the public. The secondary market or popularly called as the stock market refers to the market where these long-term financial instruments which are already issued in the primary market are traded.

\section{INDIAN STOCK MARKET}

Indian stock market is one of the oldest stock market in Asia. It dates back to the close of 18 th century when the East India Company used to transact loan securities. In the 1830s, trading on corporate stocks and shares in Bank and Cotton presses took place in Bombay. The trading was very little and it gradually improved. After a long journey, a formal stock exchange called Bombay Stock Exchange

Dr. M.Pushpalatha, Assistant Professor of Commerce IT \& E-Com, Sri Krishna Arts and Science College, Coimbatore, Tamilnadu, India.

J. Srinivasan, Assistant Professor of Commerce IT \& E-Com, Sri

G. Shanmugapriya, Assistant Professor of Commerce IT \& E-Com, Sri Krishna Arts and Science College, Coimbatore, Tamilnadu, India.
Revised Manuscript Received on September 14, 2019. Krishna Arts and Science College, Coimbatore, Tamilnadu, India.

(BSE) has evolved. In 1956, the Government of India recognized the Bombay Stock Exchange as the first stock exchange in the country under the Securities Contracts (Regulation) Act.The most decisive period in the history of the BSE took place after 1992. In the aftermath of a major scandal with market manipulation involving a BSE member named Harshad Mehta, BSE responded to calls for reform with intransigence. The foot-dragging by the BSE helped radicalise the position of the government, which encouraged the creation of the National Stock Exchange (NSE), which created an electronic marketplace. NSE started trading on 4 November 1994. The stock market index is the most importantindices of all as it measures overall market sentiment through a set of stocks that are representative of the market. The stock market is a barometer of market behavior. It reflects market direction and indicates day to day fluctuations in stock prices. The market index reflects expectations about the behavior of economy as a whole. It is a precursor of economic cycles. The function of stock index is to provide investors with information regarding the average share price in the market. Stock index is a barometer of nation?s economic health as market prices reflect expectation about the economy?s performance.During 1980?s, growth of economy was highly unsustainable because of its dependence on borrowings to correct the current account deficit. To reduce the imbalances, the government of India introduced economic policy in 1991 to implement structural reforms. The financial sector at that time was much unstructured and its scope was limited only to bonds, equity, insurance, commodity markets, mutual and pension funds. In order to structure the security market, a regulatory authority named SEBI (Securities and Exchange Board of India) was established and first electronic exchange National Stock Exchange was also set up.

\section{STOCK MARKET EFFICIENCY}

It is general notion in the market that stock markets are efficient and prices reflect all available information. There is extensive research literature available to see whether stock markets are efficient or not. Some academicians believe that stock market is weak efficient (Cootner, 1962; Fama, 19652; Kendall, 19533; Granger \& Morgenstern, 1970)4. While some others have belief that stock markets are not weak efficient (Chaudhary, 19915; Ranganatham \& Subramanian, 1993)6. The present study is an attempt to see the efficient form of Indian stock market.Efficiency of stock market has

Published By: 


\section{A Research On Volatility In The Indian Stock Market With Special Reference To Nifty And Selected Companies Offinancial Service Sector Of Nse Of India}

its implications for the whole economy and economic development of any country. As, if stock market is efficient enough then there is no need of government interference in the market movements. But, on the other side, in an inefficient market investor would like to take the benefit of extra ordinary information available to them. The role of government and the regulators increase in this situation to keep a control on significant high differences in the stock prices. There are three forms of market efficiency i.e. strong form, semi strong and weak form efficiency have different consequences as far as excess returns are concerned. If market is weak-form efficient, no excess returns can be received on the basis of study of past prices. This type of study is called technical analysis which is based on the past prices study without any further information. If market is semi-strong efficient, no excess returns can be received by the study of any publically available information. This study is called fundamental analysis, the study of companies, sectorals and the whole economy can?t produce much returns than expected compared to risk involved. If market is strong-efficient, as prices are adjusted even for secret or privately held information so no excess return can be received even by insidertrading.A stock market can be said efficient if all past information, new information and even hidden information reflect in the security prices. It is general notion in the market that stock markets are efficient and prices reflect all available information. There is extensive research literature available to see whether stock markets are efficient or not. Some academicians believe that stock market is weak efficient (Cootner, 196293; Fama,196594; Kendall, 195395; Granger \& Morgenstern, 197096). While some others have belief that stock markets are not weak efficient (Chaudhary, 199197).

\section{VOLATILITY IN INDIAN STOCK MARKET}

Volatility is basically the variation from the average value over a measurement period. If the day to day variation of the price of the securities is more, it can be said that the volatility of it will be high, and conversely if the day to day variation is low, the value of volatility will be low as well. It is measured by the standard deviation of logarithmic returns during a certain period. In the financial year 2008-09 stock markets across the globe witnessed extreme volatility. NSE Nifty came down by 179 points on 6th May 2015 due to Greek debt crisis and other problems. It came down by 490 points on 24th August 2015 due to meltdown in the Chinese stock market. On 24th June 2016, the Nifty came down by 181 points due to Brexit referendum.Over the years it has been observed that the correlation between Indian Stock Market and other world markets are on an increasing trend. This phenomenon should explain the reason for increased volatility exhibited by Indian markets during 2008-09 periods. When world markets move the valuation of Indian stocks are also affected.Investing money in stock market is assumed to be risky because stock markets are volatile. There is volatility in stock market because macro economic variables influence it and affect stock prices. These factors can affect a single firm?s price and canbespecific to a firm. On the contrary, some factors commonly affect all the firms. For example, when stock market crashed in September 2008 , the price of almost all listed companies came down.
Volatility is the variation in asset prices change over a particular time period. It is very difficult to estimate the volatility accurately. Volatility makes a stock market risky but it provides the opportunity to make money by those who can understand it. It gives the investor opportunity to take advantage of fluctuation in prices, buy stock when prices fall and sell when prices rise. So, to take advantage of volatility the need is to understand it.

\section{NEED FOR THE STUDY}

Stock Market volatility is unavoidable. It is the nature of the stock markets to fluctuate and turn red and green within short span of time. Volatility is an essential part of the stock market because it checks the nerve of the market. As a coin has two sides, the same way market has two aspects the positive and the negative. It can be seen that volatility has its long term impact in the market so an investor is required to take all possible measures to design his portfolio. Stock returns bear a good relationship with volatility as with increase in financial volatility stock prices fluctuates. An average investor gets very less returns as compared to the average market returns.

\section{OBJECTIVES OF THE STUDY}

To evaluate the return and volatility relationship in NSE Nifty and Nifty fifty Selected Companies of Financial Service Sector.

To identifies whetherNSE Nifty and Nifty fifty Selected Companies of Financial Service Sector companies are efficient or not.

\section{METHODOLOGY}

The study undertaken is analytical in nature using secondary data for the purpose of empiricalevaluation ofstock price movements and its Efficiency . In this analysis, has been taken ten companies of Financial Service Sector which are listed in Nifty 50 at the year 2018. The ten companies areAXIS,BOB,HDFC BANK,HDFC Ltd.ICICI,INDUS,KOTAK,PNB,SBIN and YES BANK .The selected period for this research study is from January 2009 to December 2018. This Paper uses various tools using like Descriptive Statistics Kolmogorov-Smirnov Test and Runs Test.

\section{RESULTS AND DISCUSSION}

ANALYSIS OF DESCRIPTIVE STATISTICS OF DAILY RETURNS OF FINANCIAL SERVICE SECTOR

Descriptive statistical analysis of returns series of AXIS, BOB, HDFC Bank, HDFCL Ltd.,ICICI, KOTAK, PNB, SBI, YESBANK and INDUSIND is presented inTable 1. In order to find the normality of the data, Jarque-bera test is employed with the support of the following hypothesis testing.

NullHypothesis(H0): The data is normally distributed for companies intheFinancial Service Sector during the study period. 
Table No.1

Descriptive Statistics for Financial Service Sector

\begin{tabular}{|c|c|c|c|c|c|}
\hline $\begin{array}{l}\text { Tool } \\
s\end{array}$ & $\begin{array}{l}\text { AXI } \\
\text { s }\end{array}$ & $\begin{array}{l}B O \\
B\end{array}$ & $\begin{array}{c}\text { HDF } \\
\text { CBA } \\
\text { NK }\end{array}$ & $\begin{array}{l}\text { FDD } \\
\text { FCL } \\
\text { Ltd. }\end{array}$ & $\begin{array}{l}\text { ICI } \\
\text { CI }\end{array}$ \\
\hline Mea & $\begin{array}{l}0.01 \\
8\end{array}$ & $\begin{array}{l}-0.0 \\
19\end{array}$ & 0.017 & $\begin{array}{l}0.0 \\
02\end{array}$ & $\begin{array}{l}-0.0 \\
33\end{array}$ \\
\hline $\begin{array}{l}\text { Medi } \\
\text { an }\end{array}$ & $\begin{array}{l}0.01 \\
8\end{array}$ & 0 & 0.014 & $\begin{array}{c}-0 \\
01 \\
1\end{array}$ & $\begin{array}{l}0.01 \\
6\end{array}$ \\
\hline $\begin{array}{l}\text { Maxi } \\
\text { mum }\end{array}$ & $\begin{array}{l}17.7 \\
53\end{array}$ & $\begin{array}{l}15.6 \\
61\end{array}$ & $\begin{array}{c}15.10 \\
1\end{array}$ & $\begin{array}{l}20 \\
27 \\
2\end{array}$ & $\begin{array}{l}20.7 \\
32\end{array}$ \\
\hline $\begin{array}{l}\text { Mini } \\
\text { mum }\end{array}$ & $\begin{array}{l}-161 \\
398\end{array}$ & $\begin{array}{r}-16 \\
1.71 \\
4\end{array}$ & $\begin{array}{c}-160 \\
546\end{array}$ & $\begin{array}{l}-15 \\
7.7 \\
69\end{array}$ & $\begin{array}{r}-16 \\
0.00 \\
6\end{array}$ \\
\hline $\begin{array}{l}\text { Std. } \\
\text { Dev. }\end{array}$ & $\begin{array}{l}4.28 \\
5\end{array}$ & 4.17 & 3.822 & $\begin{array}{l}3.9 \\
81\end{array}$ & 9 \\
\hline $\begin{array}{l}\text { Ske } \\
\text { wnes } \\
\text { s }\end{array}$ & $\begin{array}{l}-21 \\
544\end{array}$ & $\begin{array}{l}-23 \\
471\end{array}$ & $\begin{array}{l}-29.8 \\
5\end{array}$ & $\begin{array}{l}-25 \\
.01 \\
7\end{array}$ & $\begin{array}{l}-21 . \\
7>1\end{array}$ \\
\hline $\begin{array}{l}\text { Kurt } \\
\text { osis }\end{array}$ & $\begin{array}{l}814 . \\
363\end{array}$ & $\begin{array}{l}914 . \\
448\end{array}$ & $\begin{array}{l}1257 \\
412\end{array}$ & $\begin{array}{l}99 \\
6.4 \\
93\end{array}$ & $\begin{array}{l}829 . \\
364\end{array}$ \\
\hline $\begin{array}{l}\text { Jarqu } \\
\text { e-Be } \\
\text { ra }\end{array}$ & $\begin{array}{l}681 \\
346 \\
38\end{array}$ & $\begin{array}{r}859 \\
317 \\
97\end{array}$ & $\begin{array}{c}1630 \\
0000 \\
0\end{array}$ & $\begin{array}{c}1.0 \\
2 \mathrm{E} \\
+0 \\
8\end{array}$ & $\begin{array}{r}719 \\
868 \\
32\end{array}$ \\
\hline $\begin{array}{l}{ }^{\prime} \\
\text { Valu }\end{array}$ & $\begin{array}{l}0.00 \\
0=\end{array}$ & $\begin{array}{l}0.00 \\
0 \%\end{array}$ & $\begin{array}{l}0.000 \\
*\end{array}$ & $\begin{array}{l}0.0 \\
00 \\
\%\end{array}$ & $\begin{array}{l}0.00 \\
0=\end{array}$ \\
\hline
\end{tabular}

Note: * - Significant at $5 \%$ level

The above Table. 1 shows that all the companies of Financial Service sector showed sign of positive average daily returns except BOB, ICICI, PNB and SBI. The highest average daily return was shown by INDUSIND which has $0.108 \%$, followed by YESBANK with $0.095 \%$, KOTAK with $0.047 \%$, AXIS with $0.018 \%$, HDFC Bank with $0.017 \%$, HDFCLLtdwith0.002\%andthenegativereturnwasin PNBandSBIwith- $0.057 \%$, followed by ICICI with $-0.033 \%$ and BOB with $-0.019 \%$. As far as volatility was concerned the standard deviation of SBI was highest at $7.869 \%$, thereafter AXIS with standard deviation of $4.285 \%$ and the lowest volatility was present in YESBANKwith $3.102 \%$. It can be seen that INDUSIND and YESBANK has more return as well as less volatile as compared to other companies of Financial Service sector.The coefficients of the skewness were found to be significant and negative for all the returns except INDUSIND and YESBANK. The negative skewness implies that the return distributions of the shares traded in the market in the given period have a higher probability of earning returns greater than the mean. Similarly, the coefficients of kurtosis were found to be positive and were significantly higher than 3 , indicating highly leptokurtic distribution compared to the normal distribution for all the returns. That means all the companies of Financial Service sector are more risky forinvestment.The
Jarque-Bera test statistic has indicated that the null hypothesis is rejected for all thecompanies in Financial Service sector. So, it is observed that data in all the companies in Financial Service sector were not normally distributed.

\section{ANALYSIS OF KOLMOGOROV- SMIRNOVTEST OF FINANCIAL SERVICE SECTOR}

Kolmogorov-Smirnov test of return series of the Nifty and Nifty fifty Selected Companies of Financial Service Sector are presented in Table 2. In this test, the researcher has examined the series of data for the are normally distributed ornot. For this, a hypothesis framed and discussed in the following table with using K-Stest.

\section{NullHypothesis(HO):}

The return series is homogenous for the selected Nifty and Nifty Fifty Selected Companies of Financial Service Sector during the study period.

\section{Table No.3}

Kolmogorov-SmirnovTest of Nifty and Nifty Fifty Selected Companies of Financial Service Sector

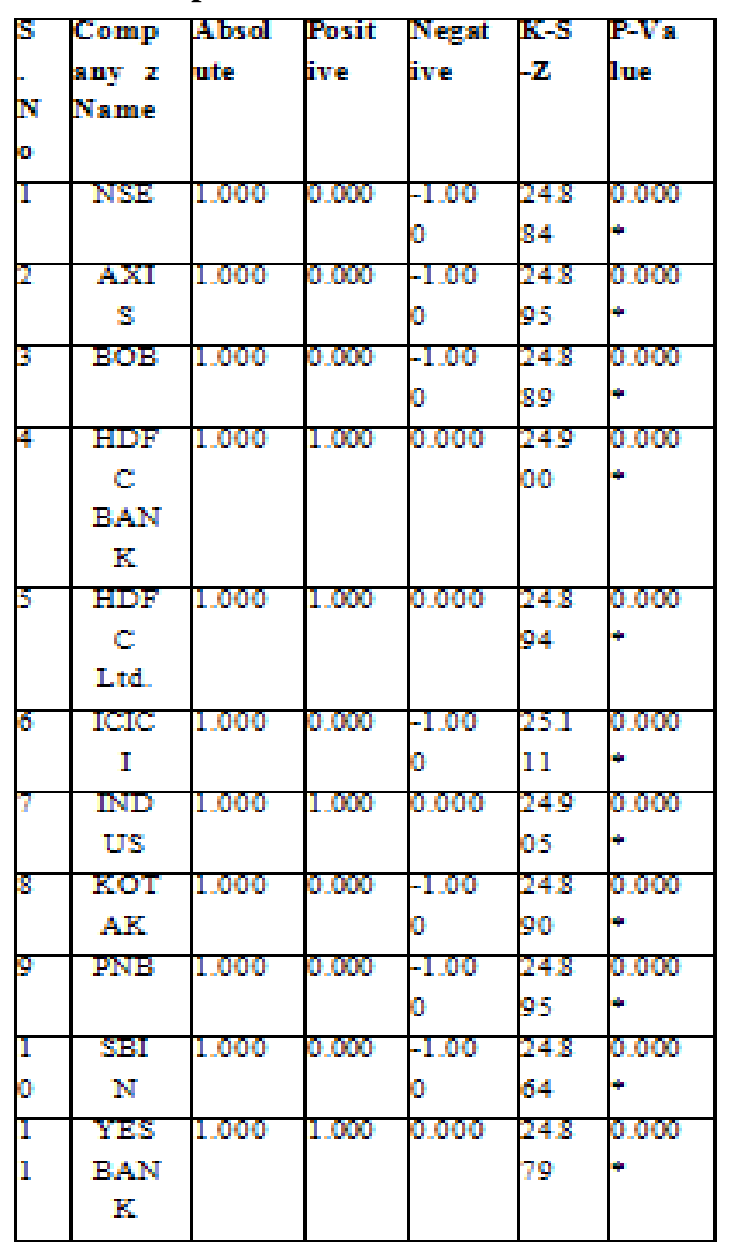

Note: * - Significant at $1 \%$ level; $* *$ -

Significant at $5 \%$ level;

NS-NotSignificant 


\section{A Research On Volatility In The Indian Stock Market With Special Reference To Nifty And Selected Companies Offinancial Service Sector Of Nse Of India}

From the above table, it is understood about the homogenous of the given return series of the Niftyand Nifty Fifty Selected Companies of Financial Service Sector companies. The result of K-S statistics was significant for all the series at $1 \%$ level which means that for a true random walk model, the null hypotheses of the selected companies are rejected and hence, it is found that the return series of theselected Niftyand Nifty fifty Selected Companies of Financial Service Sector are not homogenous. It means market did not follow random walk and were not weak form efficient.

\section{ANALYSIS OF RUNSTEST OF FINANCIAL SERVICE SECTOR}

Runs Test for returns series of Nifty and Nifty Fifty Selected Companies of Financial Service Sector ofNational Stock Exchange are presented in Table 3. Actual number of runs, expected number of runs and standard error has been calculated in this Table. Then $\mathrm{z}$-values are calculated so that they can be compared with the critical value 1.96 in order to find out whether the difference between the actual number of runs and expected number of runs is significant or insignificant. A negative $\mathrm{Z}$ value indicates a positive serial correlation, whereas a positive $Z$ value indicates a negative serial correlation. The positive serial correlation implies that there is a positive dependence of stock prices, therefore indicating a violation of random walk.

\section{Null Hypothesis $(\mathrm{HO})$ :}

Price changes of the Nifty and Nifty Fifty Selected Companies of Financial Service Sector are not dependent and mover and only.

The p-value of NSE was 0.035, AXISwith0.015,ICICI at 0.000 , YESBANK has 0.000 , so, the null hypothesis that further price changes are not dependent and move randomly, was rejected. It indicates that price changes were dependent and random walk was not followed. Hence, the return series of NSE and the Selected financial sector companies of AXIS, ICICI,YESBANK were not weak form efficient which means all past prices of the above companies stock are reflected in current stock price. Therefore, investors looking for the above said profitable companies can get profits by making an estimate of past trends.On the other hand, $p$ value indicates for all the remaining companies was greater than 0.05 and so the null hypothesis that prices move randomly and were not dependent was accepted. It indicates that the return series of all the remaining companies were weak form efficient which means all past prices of all the companies stock are not reflected in current stock price.

\section{FINDINGS OF THE STUDY}

From the analysis, it is noted that Nifty and NSE Nifty and Nifty fifty Selected Companies of Financial Service Sector were not normallydistributed.

The result of Kolmogorov-Smirnov statistics was significant for all the series at $1 \%$ level which means that for a true random walk model and hence, it is found that the return series of the selected Nifty and Nifty fifty Selected Companies of Financial Service Sector are not homogenous during the study period. It means market did not follow random walk and were not weak form efficient. Further the result showed that during the period, Indian stock market follow random walk which means market is weak form efficient and investor can take benefit on the basis of pastinformation.

The result of runs test indicating that during the study period Niftyand and Nifty fifty Selected Companies of Financial Service Sectorare significant so the null hypothesis of random behavior is accepted and hence, Indian stock market is independent and are weak form efficient. It can be concluded form the long term perspective Indian stock market is weak form efficient, the non-random behavior of the market has only short termimplications.

\section{CONCLUSION}

There was evidence from all the indices of time varying volatility which exhibited the sign of clustering, high persistence and predictability in India stock market. On the basis of results of various tests, it can be concluded that Nifty and NSE Nifty and Nifty fifty Selected Companies of Financial Service Sector is fairly weak form efficient and follow random walk during the study period. In this period, Indian stock market is approaching towards the state of fairly weak efficient market.As per the results, stock market efficiency is improving which can be the results of improvement in technology, regulation regarding disclosures, and the amount of retail participation etc.In the nutshell, with the growth of technical facilities in the capital market and removal of investment barriers, the integration of Indian stock market along with international stock markets will increase infuture.

\section{REFERENCES}

1. Aggarwal, M. (2012). Efficiency of Indian Capital Market:A Study of Weak Form of EMH on NIFTY. ACADEMICIA , 2 (6), 16-28.

2. Arindam Mandal, \& Prasun Bhattacharjee, (2012). The Indian Stock Market and the Great Recession. Theoretical and Applied Economics, 19(3),59-76.

3. Arumugam, A., \& Soundararajan, K. (2013). Stock Market Seasonality-Time Varying Volatility in the Emerging Indian Stock Market. IOSR Journal of Business and Management (IOSR-JBM), 9(6), 87-103.

4. Dyckman, T. R., \& Dale, M. (1986). Efficient Capital Markets and Accounting: A Critical Analysis. PrenticeHall.

5. Krishnaprabha, S., \& Vijayakumar, M. (2015). A Study on Risk and Return Analysis of Selected Stocks in India. International Journal of scientific research and management, 3(4), 2550-2554.

\section{WEBSITE}

a) https://www.nseindia.com/global/content/about_us/histor y_milestones.htm

b) https://www.axisbank.com/

c) https://www.icicibank.com/ 